\title{
A macroeconomic analysis of the public investments in European combined transport
}

\author{
Maria Berrittella
}

Received: 23 October 2007 / Accepted: 3 March 2009 / Published online: 1 May 2009

(C) Springer-Verlag 2009

\begin{abstract}
Intermodal transport has been recognized as a priority by the European Union, that has defined different budget allocations of investments to improve the shifting from road to intermodal transport, which is more sustainable. In this context, the main aim of the paper is to discuss the macroeconomic effects, in terms of economic growth, welfare and trade, of these public investments for combined transport, which aspects have been neglected in literature. A multi-country computable general equilibrium model has been used. The main results have been that the European Union benefits from these investments, but at international level, USA and Japan would lose in terms of welfare. Furthermore, the welfare change has been decomposed in its components and the results show that the trade effects are higher than the allocative effects. The robustness of the results has been tested over time and by a sensitivity analysis of the exchange rate.
\end{abstract}

Keywords Computable general equilibrium model $\cdot$ Public investments $\cdot$ Combined transport $\cdot$ Sensitivity analysis

JEL Classification $\quad$ C68 $\cdot$ D58 $\cdot$ H54

\begin{abstract}
Abbreviations
CGE Computable general equilibrium

$\mathrm{EV}$ Equivalent variation
\end{abstract}

M. Berrittella $(\bowtie)$

Dipartimento di Scienze Economiche, Aziendali e Finanziarie,

Università degli Studi di Palermo, Viale delle Scienze, Palermo, Italy

e-mail: maria.berrittella@unipa.it 


\section{Introduction}

Intermodal transport is the "door to door" movement of goods, using two or more modes of transport, in an integrated transport chain. The modal shift from road to other transport modes, such as rail, short sea shipping and inland waterways, which are more environmental friendly, has been recognized as a priority in the European Union (European Commission 2001). In this respect, several research projects and financing instruments have been addressed by the European Union for the promotion of intermodal transport.

The main research projects are LOGIQ (2000), which identifies the actors, criteria and constraints in the use of intermodal transport; PROMOTIQ (2000), which proposes guidelines for the intermodal transport promotion; and RECORDIT (2001), which proposes the reduction of barriers to improve the competitiveness of intermodal freight transport in Europe under the principle of sustainability. Among the financing instruments, there are: (1) Pilot Actions for Combined Transport (PACT), which aim to increase the competitiveness of combined transport by promoting the use of advanced technology (European Commission 1997); (2) the Marco Polo programme, which aims to promote the sustained modal shifts of road freight to short sea shipping, rail and inland waterway (European Commission 2003); (3) the TEN-T programme, which aims to develop trans-European transport network (European Commission 1997).

Furthermore, research on modelling covers different approaches, such as models using commodity aggregation for micro-model simulations (Nam 1997); planning models, which use advanced computer algorithms (Crainic and Laporte 1997); freight route and mode choice models, which use stated preference analysis (Cullinane and Toy 2000); intermodal freight network modelling at international level (Southworth and Peterson 2000). However, although there is a substantial literature dealing with issues related to intermodal transport, there are limited approaches for the assessment of transport policies. A rigorous work is provided by Tsamboulas et al. (2007), which developed a methodology to assess the potential of a specific policy measure for intermodal mode shift. Also the question on the evaluation of investments to promote intermodal transport has been discussed briefly in literature. Tsamboulas and Dimitropoulos (1999) discuss a methodology procedure for the assessment of the potential investments in Nodal Centres for goods-freight villages. However, it can be mainly considered as a non-formal "qualitative guidelines" for policy-makers. Gorman (2007) evaluates the public sector investment in the US freight transportation concluding that the public sector is a critical participant in creating a more efficient transportation infrastructure.

Considering the above, the analysis of modal shift is mainly faced from the supply and demand side and on the basis of the characteristics of the transport modes. Thus, a microeconomic approach has been preferred. Differently, this paper attempts to analyse the macroeconomic effects of intermodal transport network investments and their decomposition, which aspects have been neglected in literature. Banister and Berechman (2001) argue that one of the major unresolved research issues in transport is the question as to whether transport infrastructure investments promotes economic growth. This question is faced here not only in terms of economic growth, but also in 
terms of welfare and trade. Also the macroeconomic effect will be discussed at both national and international levels.

The investments planned in the Trans-European Transport (TEN-T) network for combined transport are taken into account here, which are the North-South line, the Betuwe line, the France-Italy line and the East European line. As defined by the European Commission (1992) combined transport means "the transport of goods, which uses road on the initial or final leg of the journey, and, on the other leg, either rail or inland waterway, or maritime services".

A computable general equilibrium, called GTAP (Hertel 1997), is used to discuss the macroeconomic effects of the public investments, which refer to already decided investments or budget allocations as provided by the experts from national ministries in the European Union (Planco Consulting 2003). The main results have been that European countries would benefit from these investments, but all the other countries do not gain. Furthermore, decomposing the welfare change in its components, trade effects are higher than allocative effects, and, among the lines, European countries gain substantially from the construction of the North-South line. Finally, the robustness of the results has been tested over time and by a sensitivity analysis of the exchange rate.

\section{Modelling framework}

In order to assess the systematic general equilibrium effects of the investments in combined transport, a computable general equilibrium (CGE) model, called GTAP-CTI, has been developed and applied.

CGE models build upon general equilibrium theory that combines behavioral assumptions on rational economic agents with the analysis of equilibrium conditions. To analyze the impact of a change in government policy, the CGE modellers use the comparative methodology. Initially, the model is developed such that its equilibrium replicates the transactions observed in the data. This procedure, called calibration, refers to the estimation of structural parameters of the model, based on available information on prices and quantities, normally, obtained from a Social Accounting Matrix (SAM). Moreover, the policy change is simulated by altering the relevant policy parameters and calculating the new equilibrium. For a rigorous and detailed discussion of a primer on applied general equilibrium see Kehoe and Kehoe (1994).

The main virtue of the CGE approach is its comprehensive micro-consistent representation of price-dependent market interactions. Besides, the simultaneous explanation of the origin and spending of the agents' income makes it possible to address both economy-wide efficiency, as well as distributional impacts of policy interference. Since the first CGE application by Johansen (1960), CGE models have been widely employed by various national and international organizations (IMF, World Bank, OECD, etc.), the European Commission, research institutions and universities. For survey articles see, e.g. Bhattacharyya (1996), Bergman (1990), Borges (1986), Conrad (2001), Shoven and Whalley (1992).

GTAP-CTI is a refinement of the GTAP model (Hertel 1997). The original GTAP model is a comparative static, multi-commodity, multi-region CGE model with the assumptions of perfect competition and market equilibrium. It has been widely used 
Table 1 Regional aggregation

\begin{tabular}{|c|c|c|}
\hline Acronym & Region & Countries \\
\hline USA & United States of America & United States of America \\
\hline CAN & Canada & Canada \\
\hline EU-15 and EFTA & Western Europe & $\begin{array}{l}\text { Austria, Belgium, Denmark, Finland, France, } \\
\text { Germany, Greece, Iceland, Ireland, Italy, } \\
\text { Liechtenstein, Luxembourg, The Netherlands, } \\
\text { Norway, Portugal, Spain, Sweden, Switzerland, } \\
\text { The United Kingdom }\end{array}$ \\
\hline JPK & Japan and Korea & Japan, Korea \\
\hline ANZ & Australia and New Zealand & Australia, New Zealand \\
\hline EU-12 & Central and Eastern Europe & $\begin{array}{l}\text { Bulgaria, Cyprus, Czech Republic, } \\
\text { Estonia, Hungary, Latvia, Lithunia, } \\
\text { Malta, Poland, Romania, Slovakia, Slovenia }\end{array}$ \\
\hline FSU & Former Soviet Union & Former Soviet Union \\
\hline MDE & Middle East & Turkey, Rest of Middle East \\
\hline CAM & Central America & Mexico, Central America, Carribean, \\
\hline SAM & South America & $\begin{array}{l}\text { Colombia, Perù, Venezuela, Rest of Andean Pact, } \\
\text { Argentina, Brazil, Chile, Uruguay, } \\
\text { Rest of South America }\end{array}$ \\
\hline SEA & Southeast Asia & $\begin{array}{l}\text { Taiwan, Indonesia, Malaysia, Philippines, Singapore, } \\
\text { Thailand, Vietnam }\end{array}$ \\
\hline $\mathrm{CHI}$ & China plus & China, Hong Kong \\
\hline ROW & Rest of world & Small Island States \\
\hline SAS & South Asia & Bangladesh, India, Sri Lanka, Rest of South Asia \\
\hline NAF & North Africa & Morocco, Rest of North Africa \\
\hline SSA & Sub-Saharan Africa & $\begin{array}{l}\text { Botswana, Rest of SACU, Malawi, Mozambique, } \\
\text { Tanzania, Zambia, Zimbawe, Other Southern Africa, } \\
\text { Uganda, Rest of Sub-Saharan Africa }\end{array}$ \\
\hline
\end{tabular}

and modified for analyzing the impacts of economic growth (Jorgenson 1998), international trade (Devarajan et al. 1990; Markusen et al. 1995) and environmental policies (Bosello et al. 2007, 2006).

Moreover, the GTAP-CTI model has been developed to include exogenous investments for combined transport in the European Union countries. It has been applied by aggregating the world economy from 87 into 16 regions, with each representing either a single country, or a composite region of several countries (Table 1). Each region's economy is further divided into 17 industries or commodity groups with emphasis on agriculture products, energy products and related sectors (Table 2).

According to its comparative advantages, each region produces its own unique variety of commodities using primary factors (labour, capital, land and natural resources) and intermediate inputs of domestically produced and/or imported products. 
Table 2 Industry aggregation

\begin{tabular}{|c|c|c|}
\hline Acronym & Industry & Sectors \\
\hline Rice & Rice & Paddy rice \\
\hline Wheat & Wheat & Wheat \\
\hline CerCrops & Cereals and crops & Cereal grains, crops \\
\hline VegFruits & Vegetables and fruits & $\begin{array}{l}\text { Vegetables, fruit, nuts, oil seeds, sugar cane and beet, } \\
\text { plant-based fibers }\end{array}$ \\
\hline Animals & Animals & Cattle, sheep, goats, horses, animal products \\
\hline Forestry & Forestry & Forestry \\
\hline Fishing & Fishing & Fishing \\
\hline Coal & Coal & Coal \\
\hline Oil & Oil & Oil \\
\hline Gas & Gas & Gas, gas manufacture and distribution \\
\hline Oil_Pcts & Oil products & Petroleum, coal products \\
\hline Electricity & Electricity & Electricity \\
\hline Water & Water distribution services & Water distribution services \\
\hline En_Int_Ind & Energy intensive industries & $\begin{array}{l}\text { Minerals, chemical, rubber, plastic products, } \\
\text { mineral products, ferrous metals, metals }\end{array}$ \\
\hline Oth_Ind & Other industries & $\begin{array}{l}\text { Raw milk, wool, silk-worm cocoons, meat, } \\
\text { vegetable oils and fat, dairy products, processed rice, sugar, } \\
\text { food products, beverages and tobacco products, textiles, } \\
\text { wearing apparel, leather products, wood products, } \\
\text { paper products, publishing, metals products, motor vehicles } \\
\text { and parts, transport equipment, electronic equipment, } \\
\text { machinery, manufactures }\end{array}$ \\
\hline Mserv & Market services & $\begin{array}{l}\text { Construction, trade, surface transport, sea transport, } \\
\text { air transport, communication, financial services, insurance, } \\
\text { business services, dwellings, recreation and other services }\end{array}$ \\
\hline NMServ & Non-market services & Public administration, defence, health and education \\
\hline
\end{tabular}

The production process is represented by a nested constant elasticity of substitution (CES) structure (Fig. 1):

$$
y_{i, r}=\left(\sum_{j=1}^{n} \theta_{j} x_{j}^{1-\frac{1}{\sigma}}\right)^{\frac{\sigma}{\sigma-1}}
$$

where $y_{i, r}$ is the production of the good $i$ in region $r, x_{j}$ is the input $j, \theta_{j}$ is a non-negative parameter with $\sum_{j} \theta_{j}=1, \sigma$ is the elasticity of substitution.

Each primary factor is supplied to industries from its fixed regional endowment. Labour and capital are perfectly mobile endowments and therefore earn the same market return. Land and natural resources are sluggish endowments to adjust and, hence, they sustain differential returns in equilibrium.

Commodities produced in each region are either used to meet domestic demands (as intermediate inputs in production or final products in consumption) or exported to other regions. Both intermediate and final products from different regions are considered 


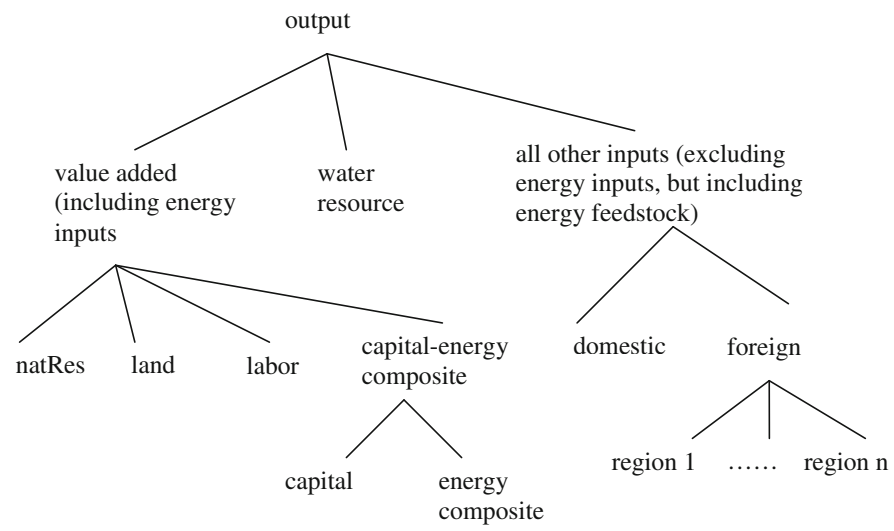

Fig. 1 Nested tree structure for industrial production process

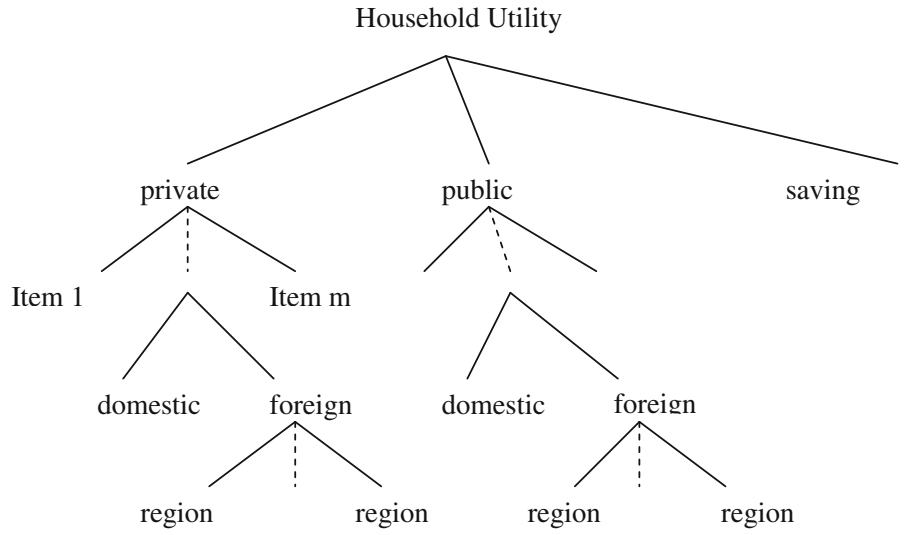

Fig. 2 Nested tree structure for final demand

to be imperfectly substitutable with each other (Armington 1969). The final demand consists of investment, government consumption, and private consumption, each of which consumes composite commodities, that are CES combinations of domestic and imported varieties (Fig. 2). Government consumption is determined by the maximization of a Cobb-Douglas utility function. A constant-difference-elasticity (CDE) utility function is used for determining private consumption.

All these elements are linked by the concept of equilibrium, which is satisfied under the following properties:

- supply equals demand for each produced good or service;

- supply equals demand in each factor market;

- transfer to the consumer equal total tax receipts.

In the standard GTAP framework, regional investments are endogenous variables. Also, savings and investments are not equalized domestically, but only at the global scale. A hypothetical "world bank" then collects savings and allocates investments, realizing the equalization of regional expected returns. For GTAP-CTI, this procedure 
has been modified in order to fix investments related to combined transport exogenously for Western Europe (EU-15 and EFTA). In fact, the investment level in EU-15 and EFTA countries has been fixed augmenting the calibration value by the percentage change, which accounts for the specific additional investment expenditure planned in the TEN-T network. To ensure the equalization of global saving and investment, an endogenous adjustment of regional savings has been set up assuming that all regional investments increase by the same percentage. In this way, the assumption of perfect international mobility of capital is respected.

\section{Design of scenarios and impact modelling}

The transport investments in EU related to combined transport, as planned by the TEN-T network, includes the construction of four lines (Table 3): (1) North-South line; (2) Betuwe line; (3) France-Italy line; (4) East European line. Figure 3 reports a map visualizing the lines under construction.

The North-South line, concerns the improvement of the North-South rail corridor from Berlin (Germany) to Naples (Italy). The project will help to reduce travel times and improve the capacity for freight transport. The Betuwe line refers to the construction of a freight transport line, which links the Port of Rotterdam with Europe's economic centres. This would allow to the Port of Rotterdam to become a major European freight transport hub. Also the shift of the freight traffic from road to rail would contribute to the reduction of pollution and enhancing road safety. The France-Italy line sets up the highspeed line from Lyon in France via Torino, Milano, Verona and Venezia to Trieste in Italy. Capacity for both passenger and freight traffic will be increased, whereas, journey times are expected to be reduced. The East European line is an important connection of the West European countries to the East European countries. The link run from Stuttgart to Salzburg (via Augsburg and Munich) to Vienna (via Linz). As for the France-Italy line, the East European line, would allow the increase of the capacity and the reduction of the journey times.

As the investments for combined transport are planned to end by 2010, the approach is based on a two-stage procedure. First, counterfactual equilibria of the world economy are generated by "pseudo-calibration" from 1997 to 2010. This entails changing the initial calibration data in the model to forecasted values of some key economic variables for 2010. The calibration data come from the GTAP database, version 5 , that contains the 1997 world economy data. The forecasted values for 2010 include estimates of population growth, endowments change of labour, capital and natural

Table 3 Combined transport investments by 2010

\begin{tabular}{lc}
\hline & $\begin{array}{l}\text { Millions Euro } \\
\text { (Millions US \$) }\end{array}$ \\
\hline 1. North-South line & $24.504(38.5)$ \\
2. Betuwe line & $1.057(1.7)$ \\
3. France-Italy line & $6.976(11)$ \\
4. East European line & $1.504(2.4)$ \\
Total combined transport investments & $34.042(53.6)$ \\
\hline
\end{tabular}




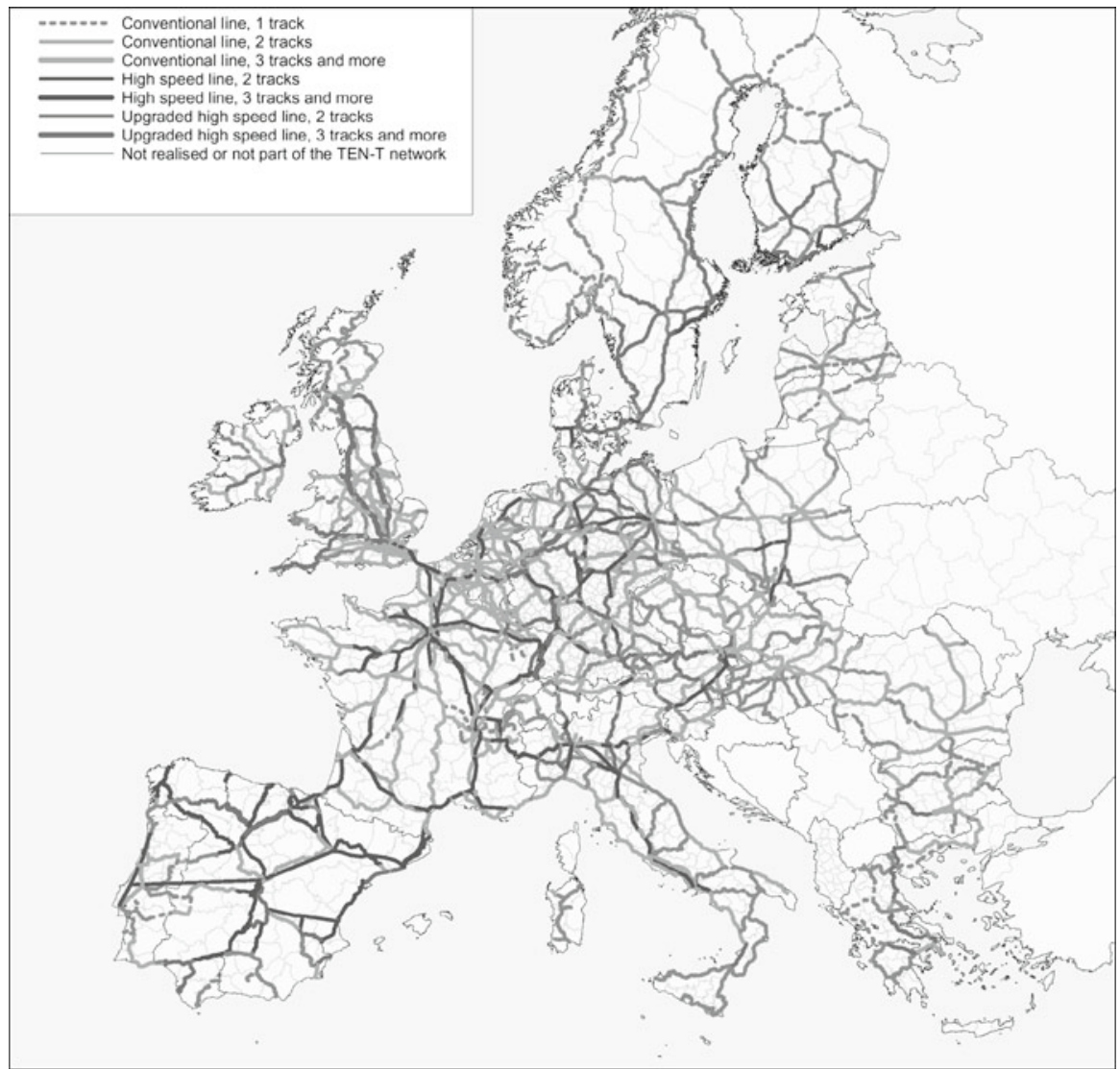

Fig. 3 TEN-T network map for 2010 according to link types (Planco Consulting 2003)

resources, productivity change of labour and land (Table 4). The resulting scenario is called "benchmark". These estimate values have been previously used for analyzing climate change impacts (Berrittella et al. 2006; Bosello et al. 2007) and sustainability (Zhang et al. 2007). Subsequently, conventional comparative analysis is conducted simulating the scenarios for 2010. Furthermore, in order to show how the results may change over time, simulations for 2050 have been also run. Estimates of population growth, endowments change of labour, capital and natural resources, productivity change of labour and land for 2050 are reported in Table 5.

The exogenous change of the investments in country $r$ induced by the variation in investments for combined transport has been computed as follows:

$$
\mu_{\mathrm{CT}, r}=\frac{I_{\mathrm{CT}, r}}{I_{r}} \times 100
$$

where $I_{\mathrm{CT}, r}$ and $I_{r}$ are, respectively, the investments of combined transport and total investment in country $r$. Moreover, the value of $I_{\mathrm{CT}, r}$ is obtained from the investments planned in the TEN-T network and reported in Table 3. The value on denominator is 
Table 4 Estimates (\% change from 1997 to 2010)

\begin{tabular}{|c|c|c|c|c|c|c|c|c|}
\hline \multirow[t]{2}{*}{ Region } & \multirow{2}{*}{$\begin{array}{l}\text { Population } \\
\text { growth (\%) }\end{array}$} & \multirow{2}{*}{$\begin{array}{l}\text { Capital } \\
\text { stock } \\
\text { change }(\%)\end{array}$} & \multirow{2}{*}{$\begin{array}{l}\text { Labour } \\
\text { stock } \\
\text { change (\%) }\end{array}$} & \multicolumn{4}{|c|}{ Labour productivity change (\%) } & \multirow{2}{*}{$\begin{array}{l}\text { Land } \\
\text { productivity } \\
\text { change }(\%)\end{array}$} \\
\hline & & & & $\mathrm{Agr}^{\mathrm{a}}$ & $E_{n} e^{b}$ & Elec $^{c}$ & Others ${ }^{\mathrm{d}}$ & \\
\hline USA & 11.29 & 42.19 & 35.74 & 23.18 & 0 & 14.95 & 29.52 & 78.24 \\
\hline CAN & 9.99 & 32.47 & 40.69 & 26.17 & 2.35 & 29.09 & 29.09 & 135.5 \\
\hline $\begin{array}{l}\text { EU-15 } \\
\text { and EFTA }\end{array}$ & 1.11 & 22.79 & 39.92 & 27.64 & 3.63 & 19.12 & 32.24 & 44.66 \\
\hline JPK & -0.9 & 53.68 & 20.17 & 26.06 & 0 & 17.64 & 29.86 & 106.41 \\
\hline ANZ & 10.38 & 32.15 & 40.69 & 25.91 & 2.32 & 28.80 & 28.80 & 135.5 \\
\hline EU-12 & -2.27 & 33.08 & 34.83 & 45.35 & 18.45 & 35.80 & 45.35 & 117.7 \\
\hline FSU & -2.26 & 35.03 & 34.83 & 48.03 & 19.54 & 37.92 & 48.03 & 117.7 \\
\hline MDE & 31.85 & 51.82 & 72.47 & 56.17 & 26.78 & 45.73 & 51.65 & 203.93 \\
\hline CAM & 21.79 & 37.51 & 74.04 & 57.79 & 27.55 & 47.04 & 64.14 & 203.93 \\
\hline SAM & 18.73 & 41.10 & 74.04 & 63.32 & 30.19 & 51.55 & 70.29 & 203.93 \\
\hline SEA & 22.89 & 52.29 & 42.32 & 62.42 & 29.76 & 50.82 & 69.02 & 206.25 \\
\hline $\mathrm{CHI}$ & 20.27 & 33.64 & 74.04 & 51.83 & 24.71 & 42.20 & 57.53 & 203.93 \\
\hline ROW & 11.85 & 45.39 & 42.32 & 54.19 & 25.84 & 44.12 & 59.92 & 206.25 \\
\hline SAS & 30.53 & 28.12 & 74.04 & 43.32 & 20.65 & 35.27 & 48.09 & 203.93 \\
\hline NAF & 36.23 & 37.56 & 74.04 & 57.87 & 27.59 & 47.11 & 64.24 & 203.93 \\
\hline SSA & 17.25 & 42.16 & 74.04 & 64.95 & 30.96 & 52.87 & 72.09 & 203.93 \\
\hline
\end{tabular}

a Agr includes Rice, Wheat, CerCrops, VegFruits, Animals, Forestry, Fishing

${ }^{\mathrm{b}}$ Ene includes Coal, Oil, Gas, Oil_Pcts, En_Int_Ind

c Elec includes electricity

d Others includes Water, Oth_Ind, MServ, NMServ

obtained from the benchmark scenario, and it is equal to the sum of the domestic and foreign investment demand.

As investments are expressed in euros in the TEN-T network, whereas GTAP database is in dollars, euro values have been converted into dollars employing an exchange rate (20 April 2008) of euro 1:1.5738 dollars. Therefore, a sensitivity analysis of its values has been run, because the exchange rate euro/dollars for 2010 will be different due to uncertainty on its value.

\section{Simulation results}

This section reports the results related to the key macroeconomic variables: trade balance, GDP and welfare.

In terms of trade, Table 6 shows that the increase of investments generates negative trade balance change for the countries of EU-15 and EFTA. In fact, these countries increase imports, in particular, of manufacturing goods and market services. The imports come mainly from Japan and USA. The opposite trade effect occurs for the other countries, which increase the exports, except for the EU-12 countries. This latter region increases the imports of market services from USA and Japan rather than from 
Table 5 Estimates (\% change from 1997 to 2050)

\begin{tabular}{|c|c|c|c|c|c|c|c|c|}
\hline \multirow[t]{2}{*}{ Region } & \multirow{2}{*}{$\begin{array}{l}\text { Population } \\
\text { growth }(\%)\end{array}$} & \multirow{2}{*}{$\begin{array}{l}\text { Capital } \\
\text { stock } \\
\text { change }(\%)\end{array}$} & \multirow{2}{*}{$\begin{array}{l}\text { Labour } \\
\text { stock } \\
\text { change }(\%)\end{array}$} & \multicolumn{4}{|c|}{ Labour productivity change (\%) } & \multirow{2}{*}{$\begin{array}{l}\text { Land } \\
\text { productivity } \\
\text { change }(\%)\end{array}$} \\
\hline & & & & $\operatorname{Agr}_{1}$ & $\mathrm{Ene}_{2}$ & $\mathrm{Elec}_{3}$ & Others 4 & \\
\hline USA & 30.4 & 253.66 & 249.63 & 120.14 & 0 & 69.45 & 100 & 114.03 \\
\hline CAN & 15.62 & 186.32 & 263.68 & 134.09 & 6.13 & 80.10 & 157.61 & 225.54 \\
\hline $\begin{array}{l}\text { EU-15 } \\
\text { and EFTA }\end{array}$ & -3.71 & 163.95 & 266.58 & 140.79 & 9.38 & 85.34 & 177.2 & 52.75 \\
\hline JPK & -11.6 & 177.5 & 214.47 & 133.59 & 0 & 79.8 & 163.07 & 162.45 \\
\hline ANZ & 18.71 & 184.77 & 263.68 & 132.98 & 6.08 & 79.43 & 156.30 & 225.54 \\
\hline EU-12 & -2.70 & 260.11 & 257.02 & 221.88 & 47.50 & 148.3 & 267.09 & 267.25 \\
\hline FSU & -2.70 & 275.50 & 257.02 & 235.01 & 50.31 & 157.082 & 282.90 & 267.25 \\
\hline MDE & 107.72 & 373.73 & 324.16 & 227.25 & 48.65 & 151.89 & 276.15 & 379.87 \\
\hline CAM & 54.90 & 375.40 & 352.43 & 287.81 & 72.78 & 197.07 & 353.24 & 379.87 \\
\hline SAM & 51.00 & 411.35 & 352.43 & 315.37 & 79.74 & 215.95 & 207 & 379.87 \\
\hline SEA & 72.57 & 500.81 & 254.43 & 346.33 & 75 & 237.14 & 330 & 339.51 \\
\hline $\mathrm{CHI}$ & 68.92 & 336.71 & 352.43 & 258.15 & 65.27 & 176.76 & 316.84 & 379.87 \\
\hline ROW & 29.36 & 463.43 & 254.43 & 251.19 & 63.51 & 172 & 306.71 & 339.51 \\
\hline SAS & 126.98 & 235.06 & 352.43 & 180.21 & 45.57 & 123.4 & 221.18 & 379.87 \\
\hline NAF & 135.78 & 375.92 & 352.43 & 288.21 & 72.88 & 197.35 & 353.73 & 379.87 \\
\hline SSA & 49.08 & 419.92 & 352.43 & 321.94 & 81.41 & 220.44 & 332.62 & 379.87 \\
\hline
\end{tabular}

${ }^{a}$ Agr includes Rice, Wheat, CerCrops, VegFruits, Animals, Forestry, Fishing

${ }^{\mathrm{b}}$ Ene includes Coal, Oil, Gas, Oil_Pcts, En_Int_Ind

c Elec includes electricity

d Others includes Water, Oth_Ind, MServ, NMServ

EU-15 and EFTA countries. Moreover, it follows that USA and Japan benefit substantially in terms of trade due to the increase in the exports of manufacturing goods and market services. Also China and South-East Asia gain in terms of trade. China mainly increases the export of manufacturing goods, whereas South-East also increases the exports of market services.

The effects of combined transport investments on GDP are positive, mainly, for European countries and China, negative for Canada, North Africa and South America. For EU-15 and EFTA the positive effect on GDP is due to the increase of investment demand. EU-12 has increased both the domestic and foreign demand of manufacturing products. These yields positive effects on GDP. China also benefits in terms of GDP increasing the production of manufacture goods and, hence, their exports. The decrease in GDP for Canada, North Africa and South America is due to the domestic demand decrease of market and non-market services.

The investments in European combined transport increases the global welfare. EU-15 and EFTA countries substantially gain in terms of welfare, also EU-12 slightly gains, but the other countries suffer losses, mainly USA and Japan. Decomposing the welfare change in its components, most of the change in welfare is due to the allocative and trade effects. Table 7 shows that these two effects have almost equal impact on equivalent variation (EV) for EU-15 and EFTA countries, but for many of 
Table 6 Macroeconomic indicators (change w.r.t. benchmark scenario 2010)

\begin{tabular}{lccc}
\hline & $\begin{array}{l}\text { Trade balance } \\
\text { (Millions \$) }\end{array}$ & GDP $(\%)$ & $\begin{array}{l}\text { Welfare } \\
\text { (Millions \$) }\end{array}$ \\
\hline USA & 9,717 & -0.001 & $-1,301$ \\
CAN & 1,369 & -0.024 & -424 \\
EU-15 and EFTA & $-43,929$ & 0.051 & 12,228 \\
JPK & 13,689 & -0.004 & $-1,912$ \\
ANZ & 954 & -0.011 & -248 \\
EU-12 & -187 & 0.007 & 47 \\
FSU & 1,295 & -0.009 & -417 \\
MDE & 1,257 & -0.013 & -689 \\
CAM & 847 & -0.007 & -185 \\
SAM & 3,030 & -0.015 & $-1,031$ \\
SAS & 1,570 & -0.003 & -266 \\
SEA & 4,200 & -0.004 & -450 \\
CHI & 5,087 & 0.005 & -576 \\
NAF & 413 & -0.018 & -192 \\
SSA & 382 & -0.005 & -113 \\
ROW & 305 & -0.006 & -90 \\
\hline
\end{tabular}

Table 7 Welfare contributions

\begin{tabular}{lccc}
\hline & $\begin{array}{l}\text { Welfare change } \\
\text { (Millions } \$, \\
\text { w.r.t. 2010) }\end{array}$ & $\begin{array}{l}\text { Share of } \\
\text { allocative } \\
\text { effects }(\%)\end{array}$ & $\begin{array}{l}\text { Share of trade } \\
\text { effects }(\%)\end{array}$ \\
\hline USA & -1300.52 & 5.00 & 70.21 \\
CAN & -424.261 & 48.21 & 55.49 \\
EU-15 & 12228.29 & 46.92 & 54.11 \\
and EFTA & & & \\
JPK & -1912.38 & 12.59 & 134.76 \\
ANZ & -247.705 & 27.09 & 68.93 \\
EU-12 & 47.27803 & 59.94 & -153.15 \\
FSU & -416.596 & 19.84 & 70.39 \\
MDE & -689.045 & 22.33 & 68.02 \\
CAM & -184.534 & 25.59 & 52.65 \\
SAM & -1030.64 & 36.14 & 37.66 \\
SAS & -266.192 & 9.24 & 75.73 \\
SEA & -450.128 & 13.46 & 89.08 \\
CHI & -576.3 & -13.41 & 101.15 \\
NAF & -192.378 & 32.82 & 60.81 \\
SSA & -112.903 & 24.83 & 60.19 \\
ROW & -90.0203 & 30.79 & 52.62 \\
\hline
\end{tabular}


Table 8 Welfare change per line (millions \$ w.r.t. benchmark scenario 2010)

\begin{tabular}{lcccc}
\hline & North-South line & Betuwe line & France-Italy line & East European line \\
\hline USA & -934 & -40 & -265 & -57 \\
CAN & -305 & -13 & -86 & -19 \\
EU-15 and EFTA & 8,795 & 379 & 2,500 & 539 \\
JPK & $-1,373$ & -59 & -389 & -84 \\
ANZ & -178 & -8 & -51 & -11 \\
EU-12 & 34 & 1 & 9 & 2 \\
FSU & -300 & -13 & -85 & -18 \\
MDE & -497 & -21 & -142 & -31 \\
CAM & -133 & -6 & -38 & -8 \\
SAM & -741 & -32 & -211 & -45 \\
SAS & -191 & -8 & -54 & -12 \\
SEA & -323 & -14 & -92 & -20 \\
CHI & -413 & -18 & -117 & -25 \\
NAF & -139 & -6 & -39 & -9 \\
SSA & -81 & -4 & -23 & -5 \\
ROW & -65 & -3 & -18 & -4 \\
World & 3,156 & 136 & 899 & 194 \\
\hline
\end{tabular}

other regions, the trade effect is significantly higher than the allocative effect on EV. For Japan the contribution of the trade effect to the EV is higher than the same EV, this comes from the fact that Japan strongly increases the exports of manufacturing products. For China and EU-12 countries the two effects are opposite. The positive contribution of the allocative effects to $\mathrm{EV}$ is due to the taxation of the production of manufacturing goods, whereas their export increase yield a negative contribution to EV in terms of trade. However, the compensation of the two effects has opposite results in the two regions, EU-12 obtains an increase in welfare, whereas China's welfare decreases. Considering that the allocative effects come mainly from taxation of imports and exports, the additional spending generated by investments yields a shift from domestic to foreign market, in particular, there is an increase of manufacturing products trade.

Furthermore, the comparison of the scenarios shows that the European Union would benefit mainly from the improvement of the North-South rail corridor (Table 8). The Betuwe line and the East European line are not much relevant.

Over time from 2010 to 2050, the magnitude of the welfare effects increases, in particular, positively for EU-15 and EFTA (533\%) and negatively for Japan (-457\%), for the other countries, in absolute terms, the welfare change is about $350 \%$ (Fig. 4).

Furthermore, due to uncertainty on the exchange rate euro/dollars for 2010, a sensitivity analysis of its values has been run. The method has involved specification of certain number of experiments, which set different possible values of the exchange rate, $w_{i}$, which has been supposed to evolve according to the stochastic differential equation: 


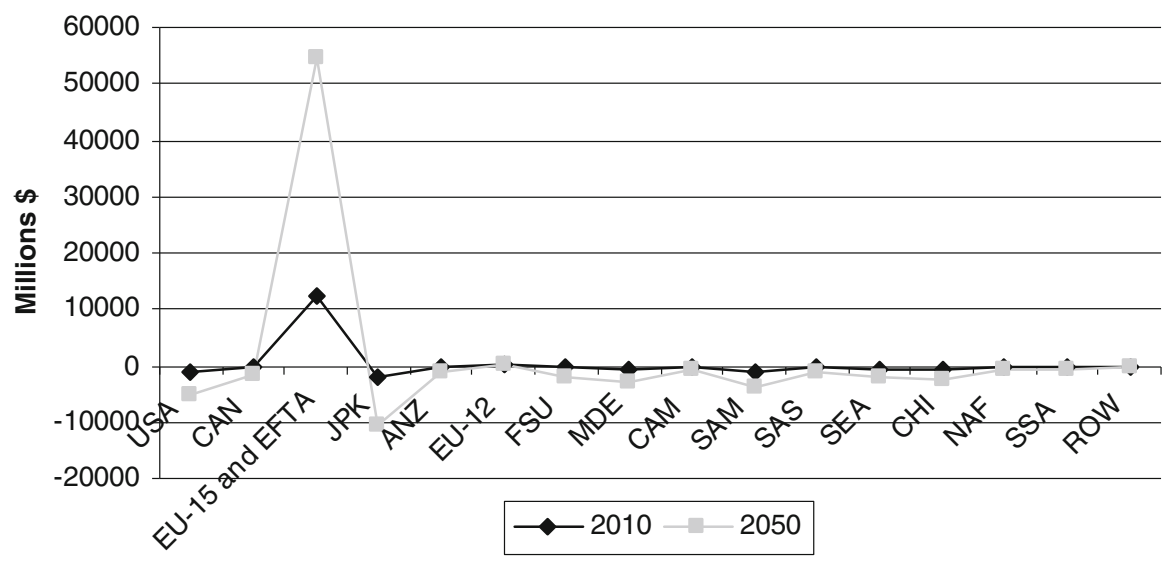

Fig. 4 Welfare comparison over time

$$
\mathrm{d} w_{i}=\mu w_{i} \mathrm{~d} t+\sigma w_{i} \mathrm{~d} z
$$

This equation implies that $w_{i}$ is changing according to a process of geometric Brownian motion. The term $\mu \mathrm{d} t$ is the mean or expected percentage change in $w_{i}$ for the increment $\mathrm{dt}$, and $\mu$ is called the mean drift rate. The term $\sigma \mathrm{d} z$ introduces a random component to the drift, because $\mathrm{d} z=\varepsilon(t) \sqrt{\mathrm{d} t}$, where $\varepsilon(t)$ is a normally distributed random variable with 0 mean and standard deviation of 1 . A discrete approximation of (3) is given by the stochastic difference equation:

$$
\mathrm{d} w_{i, t+1}=(1+\mu) w_{i, t}+\sigma w_{i, t} \varepsilon_{t+1}
$$

where the $\varepsilon_{t+1}$ are the standard normal variates and the implied increment is $\mathrm{d} t=1$.

Given the initial value of the exchange rate of euro 1:1.5738 dollars (20th April 2008) and the values for $\mu$ and $\sigma$, selected from the standard normal distribution defined for the $95 \%$ confidence interval, a sample path of 100 random numbers has been generated.

Figure 5 reports the upper $(\max )$ and lower $(\mathrm{min})$ bound case of the exchange rate. The results confirms the robustness of previous findings: the EU-15 and EFTA countries substantially gain, EU-12 slightly benefits, USA and Japan are the main losers.

\section{Conclusions}

This paper has attempted to discuss the macroeconomic effects of combined transport investments in the European Union, which have been neglected in literature. A multicountry, multi-region CGE model, called GTAP, has been used. This has allowed analysing not only the macroeconomic impacts in the European Union, but also in other countries. The construction of four rail lines has been taken into account: the North-South, the Betuwe, the France-Italy and the East European. 


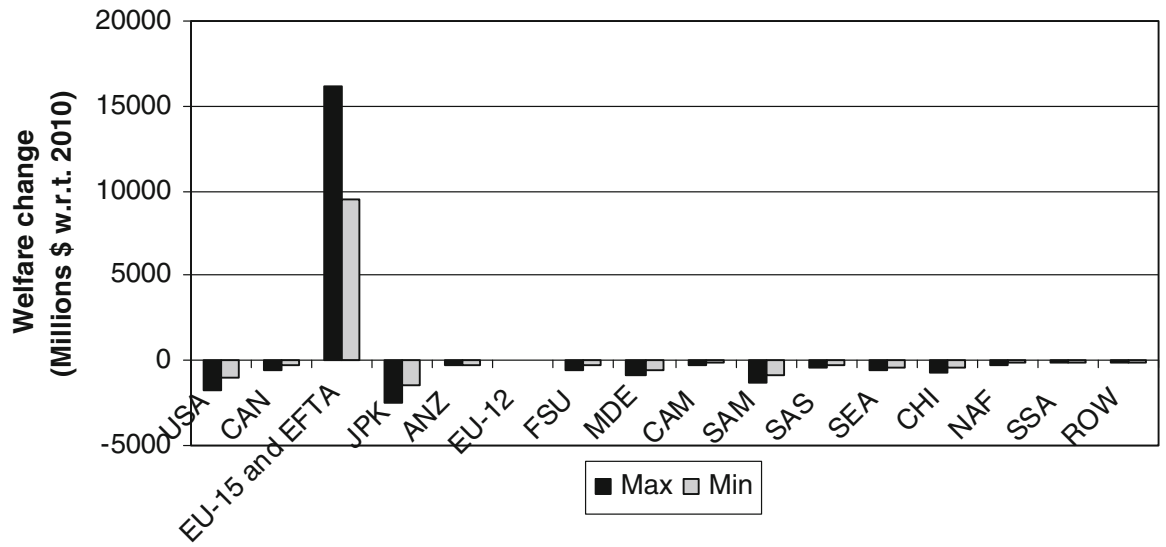

Fig. 5 Sensitivity analysis of the exchange rate

European Union will benefit from all of them, the construction of the North-South line would contribute substantially to the increase of the welfare in the European Union. Thus, to invest in order to improve the combined transport would allow not only the reduction of travel times and congestion, and the increase of capacity of the rail network, but also benefits in macroeconomic terms in the European Union. The main losers are the USA and Japan. However, globally, the welfare increases. Decomposition of the welfare change in its components shows that the trade effect is significantly higher than the allocative effect. Finally, these results are robust both over time and with the application of different exchange rate.

Acknowledgments I would like to thank two anonymous reviewers for useful comments and suggestions.

\section{References}

Armington A (1969) Theory of demand for products distinguished by place of production. IMF Staff Pap 16:159-178

Banister D, Berechman Y (2001) Transport investment and the promotion of economic growth. J Transp Geogr 9:209-218

Bergman L (1990) The development of computable general equilibrium modeling. In: Bergman L, Jorgenson DW, Zalai E (eds)General equilibrium modeling and economic policy analysis. Basil Blackwell, Cambridge, pp 3-30

Berrittella M, Bigano A, Roson R, Tol RSJ (2006) A general equilibrium analysis of climate change impacts on tourism. J Tour Manag 27:913-924

Bhattacharyya SC (1996) Applied general equilibrium models for energy studies: a survey. J Energy Econ 18:145-164

Borges A (1986) Applied general equilibrium models: an assessment of their usefulness for policy analysis. OECD Econ Stud 7:7-43

Bosello F, Roson R, Tol RSJ (2007) Economy_wide estimates of the implications of climate change: sea level rise. J Env Res Econ 37:549-571

Conrad K (2001) Computable general equilibrium models in environmental and resource economics. In: Tietenberg T, Folmer H (eds) The international yearbook of environmental and resource economics 2002/2003. pp 66-114

Crainic TG, Laporte G (1997) Planning models for freight transportation. Eur J Operat Res 97:409-438 
Cullinane K, Toy N (2000) Identifying influential attributes in freight route/mode choice decisions: a content analysis. Transp Res Part E 36:41-53

Devarajan S, Lewis JD, Robinson S (1990) Policy lessons from trade focused, two-sector models. J Policy Model 12:625-657

European Commission (1992) Council directive on the establishment of common rules for certain types of combined transport of goods between Member States (COM/92/106)

European Commission (1997) Communication from the Commission to the European Parliament and the Council on intermodality and intermodal freight transport in the European Union: a systems approach to freight transport, strategies and actions to enhance efficiency, services and sustainability (COM/97/243 final)

European Commission (2001) White Paper, European transport policy for 2010: time to decide (COM/01/370 final)

European Commission (2003) Proposal for a Directive of the European Parliament and of the Council on intermodal loading units (COM/03/155 final)

Gorman MF (2007) Evaluating the public investment mix in US freight transportation infrastructure. Transp Res Part A 42:1-14

Hertel TW (1997) Global trade analysis: modeling and applications. Cambridge University Press, Cambridge

Johansen L (1960) A multi-sectoral study of economic growth, 2nd edn. North-Holland, Amsterdam

Jorgenson D (1998) Growth: energy, the environment, and economic growth, vol 2. MIT, Cambridge

Kehoe PJ, Kehoe TJ (1994) A primer on static applied general equilibrium models. Fed Reserve Bank Minneap Q Rev 18(2)

LOGIQ (2000) Intermodal decision: the decision-making process in intermodal transport. Final report. Research project of the 4th framework programme on research and development of the European Commission

Markusen JR, Rutherford TF, Hunter L (1995) Trade liberalization in a multinational-dominated industry. J Int Econ 38:95-118

Nam K (1997) A study of the estimation and aggregation of disaggregate models of mode choice for freight transport. Transp Res Part E 33:223-231

Planco Consulting (2003) Transport Infrastructure Costs and Investments between 1996 and 2010 on the Trans-European transport network and its connection to neighbouring regions, including an inventory of the technical status of the transport-European transport network for the year 2000. Final report, Planco Consulting GmbH, Essen, Germany

PROMOTIQ (2000) Conditions for the promotion of a new generation of intermodal transport services and operators. Final report. Research project of the 4th framework programme on research and development of the European Commission

RECORDIT (2001) Real cost reduction of door-to-door intermodal transport. Final report. Research project of the 4th framework programme on research and development of the European Commission

Shoven JB, Whalley J (1992) Applying general equilibrium. Cambridge University Press, Cambridge

Southworth F, Peterson B (2000) Intermodal and international freight network modeling. Transp Res Part C 8:147-166

Tsamboulas D, Dimitropoulos I (1999) Appraisal of investments in European nodal centres for goodsfreight villages: a comparative analysis. Transportation 26:381-398

Tsamboulas D, Vrenken H, Lekka A (2007) Assessment of a transport policy potential for intermodal mode shift on a European scale. Transp Res Part A 41:715-733

Zhang J, Dobranskyte A, Berrittella M (2007) Impacts of global multilateral trade liberalization on sustainability indicators. J Econ Integr 22:995-1018 